\title{
"Aquilo que nos faz humanos": cotidiano e resistência feminina afro-brasileira em Reza de mãe, de Allan da Rosa
}

\author{
"What Makes Us Human": Everyday Life and Female \\ Afro-Brazilian Resistance in Allan da Rosa's Reza de mãe \\ "Aquello que nos hace humanos": cotidiano y resistencia \\ femenina afrobrasileña en Reza de mãe de Allan da Rosa
}

Cecília Paiva Ximenes Rodrigues

\section{Resumo}

No artigo "Doente de Brasil" (2019), Eliane Brum expõe como os brasileiros têm adoecido mental e fisicamente diante do crescente autoritarismo político-social, desde 2016, e da sua consolidação na figura do atual presidente. Brum se pergunta como combater esse estado de coisas que adoece indivíduos e coletividade; e a resposta surge nos últimos parágrafos, apontando para a cultura como antídoto. Não uma cultura das elites, mas, sim, "aquilo que nos faz humanos", utilizando a palavra como mediadora e reamarrando laços para fazer comunidade. Atos diários de resistência, tão recorrentes na história afrobrasileira, compõem uma das temáticas de Reza de mãe (2016), coletânea de contos de Allan da Rosa. Enquanto as histórias gravitam em torno do duro cotidiano dos afro-brasileiros em comunidades de São Paulo, dois contos trabalham ainda a reapropriação feminina do cotidiano, não apenas como modo de resistência, mas também de busca por "aquilo que nos faz humanos". Diante de tal contexto, este artigo dialoga com a teoria desenvolvida por Michel de Certeau em A invenção do cotidiano (1980) para analisar as personagens femininas afro-brasileiras dos contos "Pode ligar o chuveiro?" e "Reza de mãe". Ao conferir centralidade a tais personagens, os contos estabelecem um lugar de fala no qual a mulher negra e periférica se delineia agente da (sua) história. São tecidas, por fim, considerações a respeito dos diferentes gêneros literários presentes na coletânea, uma vez que o poema introdutório "Desculpa perguntar" e o apólogo "O barco" funcionam como moldura temática ao abordarem opressão e resistência.

Palavras-chave: mulheres afro-brasileiras, cotidiano, resistência, Allan da Rosa.

\section{Abstract}

In her article "Doente de Brasil" (2019), Eliane Brum reveals how Brazilians have gotten mentally and physically sick due to the increasing socio-political authoritarianism since 2016 and its consolidation with the new president. Brum discusses how to fight this state of affairs that is sickening individuals and the collectivity. Her answer argues for culture as an antidote. Not the culture of elitism, but one "that makes us human", utilizing the word as a mediator and reestablishing ties to build community. Daily acts of resistance, so recurrent in Afro-Brazilian history, compose one of the thematic areas in Reza de mãe (2016), a short story collection by Allan da Rosa. While the stories revolve around Afro-Brazilians' harsh everyday life in poor communities in São Paulo, two short stories address the female reappropriation of everyday life not only as a

\section{Resumen}

En el artículo "Doente de Brasil" (2019), Eliane Brum revela cómo los brasileños se han enfermado mentalmente y físicamente frente al creciente autoritarismo político-social, desde 2016, y a su consolidación en la figura del actual presidente. Brum se pregunta cómo combatir este estado de cosas que enferma a los individuos y a la colectividad. La respuesta apunta a la cultura como antídoto. No una cultura de las élites, sino "lo que nos hace humanos", utilizando la palabra como mediadora y estrechando lazos para construir comunidad. Actos diarios de resistencia, tan recurrentes en la historia de los afrobrasileños, componen una de las temáticas de Reza de mãe (2016), colección de cuentos de Allan da Rosa. Mientras las historias gravitan alrededor de la dura cotidianidad de los afrobrasileños en comunidades de São Paulo, dos de los cuentos trabajan la reapropiación femenina de lo cotidiano no sólo

\footnotetext{
* University of Georgia, Athens, Georgia, Estados Unidos. (Dorcid.org/0000-0002-2460-1017. E-mail: ceciliar@uga.edu
} 
means of resistance, but also as a search for that which "makes us human". Given this context, this article dialogues with the theory developed by Michel de Certeau in The Practice of Everyday Life (1980) to analyze the AfroBrazilian female characters in the stories "Pode ligar o chuveiro?" and "Reza de mãe". By granting central stage to the characters, the stories establish a locus of enunciation in which black and peripheral women become agents of their own story/history. I also raise considerations regarding the formative role of distinct literary genres, as the opening poem "Desculpa perguntar" and the apologue "O barco" provide a thematic frame for addressing oppression and resistance.

Keywords: Afro-Brazilian women, everyday life, resistance. como medio de resistencia, sino también en búsqueda de "lo que nos hace humanos". Delante de dicho contexto, este artículo dialoga con la teoría desarrollada por Michel de Certeau en La invención de lo cotidiano (1980) para analizar los personajes femeninos afrobrasileños de los cuentos "Pode ligar o chuveiro?" y "Reza de mãe". Al conferir centralidad a estos personajes, los cuentos establecen un lugar de enunciación en el que la mujer negra y periférica se delinea agente de la (su) historia. Además, haré consideraciones sobre los diferentes géneros literarios presentes en la colección, puesto que el poema introductorio "Desculpa perguntar" y el apólogo "O barco" sirven como marco temático al abordar la opresión y la resistencia.

Palabras-clave: mujeres afrobrasileñas, cotidianidad, resistencia.

Um dos temas mais debatidos na conferência da Associação Americana de Estudos Lusófonos (APSA) realizada em 2018, em Michigan, Estados Unidos, foi como resistir a tempos de recessão democrática como a que passa o Brasil do pós-golpe e a consequente ascensão da extrema direita. $\mathrm{O}$ congresso ocorreu de 18 a 20 de outubro, uma semana antes das eleições do segundo turno que confirmariam Jair Bolsonaro presidente no dia 28 daquele mês. A palestra de abertura funcionou como uma terapia em grupo, com um palestrante à beira das lágrimas e o público compartilhando experiências de profunda decepção nas quais o cenário político invadia o âmbito da vida pessoal. Houve relatos de amizades e relações familiares desfeitas e aturdimento diante de intolerâncias inesperadas.

Como comprovamos de lá para cá, esse estado de coisas permeado de conflito e divisão só se intensificou. Em recente artigo publicado pelo jornal El País, intitulado "Doente de Brasil", Eliane Brum (2019) expõe como os brasileiros têm adoecido mental e fisicamente em face do crescente autoritarismo político-social. Ao final do artigo de opinião, Brum se pergunta como combater as circunstâncias que adoecem tanto os indivíduos quanto a coletividade, e a resposta surge tímida nos últimos parágrafos, apontando para a cultura como antídoto. Não uma cultura das elites, mas, sim, "aquilo que nos faz humanos", utilizando "a palavra como mediadora e reamarrando laços para fazer comunidade" (s.p.). Em outras palavras, atos de resistência emanam da vida nossa de cada dia e têm a linguagem como uma de suas matérias-primas.

Ainda registrando a troca de experiências da conferência da APSA e em diálogo com os questionamentos de Brum, quando indagado sobre como resistir com um mínimo de esperança diante do contexto sociopolítico, não apenas brasileiro, mas mundial, o músico e escritor angolano radicado na Alemanha, Kalaf Epalanga, não titubeou ao afirmar que, se quisermos aprender a resistir, teremos que procurar caminhos na história secular de resistência das mulheres negras. ${ }^{1}$ Por meio delas, que sempre estiveram na base da pirâmide social, racial e de gênero, encontramos estratégias de sobrevivência para tempos de crise. Elas, que sempre carregaram o peso de uma narrativa que as desumanizava, são um portal para que nós, com humildade, aprendamos sobre a potência de outros modos de existir.

\footnotetext{
${ }^{1}$ Como demonstra o livro organizado por Dalcastagnè, Licarião e Nakagome, Literatura e resistência (2018), são múltiplas as fontes que oferecem estratégias de resistência: mulheres, afro-brasileiros, indígenas, comunidade LGBT, escritores e especialistas de várias regiões do país. A partir da mesma indagação acerca do papel da cultura diante da crise, os textos que compõem a coletânea destacam o papel da literatura como espaço de resistência e questionamento do mundo. O presente estudo dialoga com esses esforços críticos ao focar especificamente a experiência das mulheres afro-brasileiras.
} 
É, portanto, consciente dessa oportunidade de aprendizado que teço considerações acerca da resistência feminina afro-brasileira em algumas personagens dos contos "Pode ligar o chuveiro?" e "Reza de mãe", que fazem parte da coletânea Reza de mãe, de Allan da Rosa, publicada em 2016. Partindo da premissa de que o indivíduo, no processo de interação social, atua na construção de sentidos suplementares ao discurso vigente e canônico, o estudo das personagens Nefertiti, Dona Esperança e Pérola será desenvolvido a partir da ressignificação do seu cotidiano como modo de resistência e de busca por "aquilo que nos faz humanos". A interação entre uma realidade opressora e o desenvolvimento de estratégias de resistência estabelece um elo dialógico com a teoria do cotidiano de Michel de Certeau. Em seu célebre A invenção do cotidiano (1998), o crítico francês defende a teoria de que sob a realidade opressora dos poderes e das instituições, observase um movimento de resistência por parte da multidão anônima que, diante da dominação, metamorfoseia leis e práticas segundo seus interesses próprios e recria seu cotidiano de maneira criativa. Certeau analisa de que maneira as pessoas comuns lançam mão de práticas diárias "maneiras de fazer" (p. 41) - como forma de resistir à ordem social dominante que lhes é imposta, e fazem isso não rejeitando ou alterando a dita ordem, mas adaptando-a a seus próprios fins. Esse deslocamento pendular entre opressão e resistência é dividido por Certeau em estratégia e tática. Por um lado, a estratégia equivale às relações de força que fazem surgir ordens sociais disciplinatórias, tais como a nacionalidade política, econômica ou científica (p. 47); por outro, a tática equivale ao lugar do outro e se caracteriza pela ausência de poder (p. 101). Nesse sentido, a estratégia busca manipular a partir da criação de um lugar de poder como forma de circunscrever seu campo de controle, ao passo que a tática se delineia pela ausência de um espaço e, por conta da sua natureza não institucionalizada, opera por meio do uso pertinente do tempo, funcionando nas fendas do sistema (p. 101-102). ${ }^{2}$

Nesse viés interpretativo, analiso as personagens femininas afro-brasileiras e como elas desenvolvem táticas para driblar a opressão secular que têm sofrido, uma vez que sua resistência se inscreve no texto tanto pela ressignificação do espaço opressor das instituições quanto por meio do registro da memória, religião e narrativa afro-brasileiras. Teço, ainda, considerações a respeito dos diferentes gêneros literários presentes na coletânea: o poema introdutório "Desculpa perguntar" e o apólogo "O barco", que, como argumento, funcionam como moldura temática ao abordarem a opressão e a resistência, respectivamente. Por fim, faço uma análise sobre como os nomes das personagens redimensionam positivamente a mulher afro-brasileira, além de aludirem à sua trajetória de resistência.

\section{"Questionar o sistema e suas pauladas no cotidiano"}

Ao conferir centralidade ao sujeito afro-brasileiro, exposto à violência secular e posicionado de maneira subalterna no discurso dominante, os contos de Rosa estabelecem um lugar de fala no qual o afro-descendente se delineia como agente da (sua) história. O escritor e capoeirista integra o movimento de Literatura Periférica de São Paulo desde o início. ${ }^{3}$ Historiador e doutorando na Faculdade de Educação da USP, desenvolve pesquisa no Núcleo de Consciência Negra, foi professor e alfabetizador, pesquisa e atua em ancestralidade, imaginário e cotidiano negro (Guimarães, 2016). Rosa é extremamente atuante e engajado socialmente: organiza cursos autônomos de estética e política afro-brasileira; faz workshops em universidades, bibliotecas e centros comunitários do Brasil e do exterior (Cuba, Moçambique, Estados Unidos, Colômbia, Bolívia e Argentina). No campo da produção literária, criou o selo Edições Toró, de perfil alternativo, com publicações marcadas por um trabalho artesanal e pela presença de autores jovens, sem espaço no mercado editorial. Como escritor, incorpora em sua linguagem a tradição

\footnotetext{
${ }^{2}$ Vale ressaltar que a cultura brasileira foi uma das analisadas por Certeau para o desenvolvimento da sua teoria do cotidiano. A partir de pesquisas realizadas no Rio de Janeiro, Salvador e Recife, o teórico discorre não só sobre o espaço utópico criado a partir de práticas narrativas religiosas, mas também sobre a presença ubíqua, em diversas culturas, de "maneiras de usar" sistemas opressores por meio do desenvolvimento de táticas de resistência.

${ }^{3}$ Como observa Lucía Tennina (2017, p. 31), Allan da Rosa organizou o Primeiro Encontro de Literatura Periférica de São Paulo em 2005 e seu livro de poesia Vão se tornou referência deste evento inaugural.
} 
da cultura negra e experimenta diversas formas literárias, como a prosa, a poesia e o texto dramático. É autor do livro de poemas Vão (2005), da peça teatral Da Cabula (2006, vencedora do Prêmio Nacional de Dramaturgia Negra), do infantojuvenil Zagaia (2007) e da coletânea de contos Reza de Mãe (2016) (Allan..., 2018).

Publicado pela Editora Nós, uma jovem editora de São Paulo que tem como missão difundir projetos literários inovadores e inclusivos, Reza de mãe apresenta quinze textos (catorze contos e um poema introdutório). Os contos dialogam entre si não apenas por meio de personagens que aparecem em várias histórias, mas, especialmente, por elencar temas relevantes à realidade afrobrasileira e periférica no Brasil, a saber: racismo e preconceito; ausência do Estado e opressão da polícia; humilhação por meio da interação com as classes média e alta. Cada conto aborda uma adversidade específica, que se origina de um cotidiano de "segregação socioespacial", segundo Tennina (2017, p. 13), seja abordando a falta de infraestrutura da periferia de São Paulo e a precariedade do transporte público, seja revelando confrontos entre a polícia e os cidadãos ou, ainda, retratando os conflitos humanos provenientes desse contexto.

Sobre o escopo da obra, em entrevista concedida a Juca Guimarães (2016), Rosa comenta:

A busca deste livro é se desvencilhar do fácil maniqueísmo, que é uma imensa tentação pra nossa arte há tempos e pode engessar e congelar a compreensão. O desafio é se enredar em nossos labirintos, ir pra além das noções simplistas de bom e de mau. Questionar o sistema, suas pauladas em nosso cotidiano, sua força racista em nossa história, mas também se emaranhar nas nossas dúvidas, necessárias em tempo de tanta exclamação raivosa e rasa (Rosa, 2016a, s.p.).

A avaliação de Rosa sobre sua própria obra, quando nela enfatiza a necessidade de "questionar o sistema e suas pauladas no cotidiano", dialoga com os estudos críticos sobre sua prática literária. Na ainda acanhada fortuna crítica sobre sua obra, é patente o destaque ao indivíduo comum e sua rotina. Gustavo Bicalho (2018, s.p.) comenta que nos textos de Rosa observa-se a "apreensão da vida de seus moradores em suas angústias, desafios e ambições reais, não folclóricos. A existência cultural que se depreende dos viveres periféricos é, assim, tecida em sua pluralidade". Fernanda Figueiredo e Glauber Ribeiro (2017, s.p.), por sua vez, ressaltam "que sua escrita mostra, por traço essencial, reproduzir a fala coloquial, valorizar a cultura popular brasileira, a vida simples e as pessoas à margem da sociedade".

Para que se possa falar do indivíduo e seu cotidiano em Rosa é imprescindível situá-lo no espaço em que habita, o território da periferia brasileira, tão forâneo às classes média e alta. ${ }^{5}$ Nesses bairros aparentemente caóticos, com sua fiação ilegal, ruelas labirínticas e infraestrutura precária, existe, na verdade, uma organização implícita. A esse respeito, Paulo Patrocínio (2011) comenta que se trata do trabalho, muitas vezes coletivo, dos moradores, que tentam melhorar suas condições de vida através da transformação desse espaço (com a construção de "puxadinhos" e a abertura de frestas para entrar a brisa). Em outras palavras, diante de bairros formados de maneira precária, uma estrutura física opressora equivalente à estratégia definida por Certeau, observa-se a criatividade de se transformar esse espaço de acordo com interesses e necessidades pessoais, as chamadas táticas pelo teórico. Essa intervenção por parte dos próprios moradores revela "espaços em transformação, pulsando a vida dos que lá residem" (Patrocínio, 2011, p. 58). Os textos de Rosa têm, portanto, como pano de fundo os bairros dos subúrbios brasileiros e é nesse cenário que o escritor alinhava a "vida simples das pessoas à margem da sociedade" e as "pauladas no cotidiano" que experimentam, sem deixar de enfatizar "a pluralidade que é tecida a partir desses viveres periféricos" (Bicalho, 2018, s.p.).

Quase todas as narrativas de Reza de mãe possuem um narrador onisciente, ao passo que a voz das personagens é inserida por meio de travessões nos diálogos e itálico ou aspas nos

\footnotetext{
${ }^{4}$ Allan da Rosa conta ainda com uma bibliografia extensa de trabalhos publicados em coautoria, de participação em antologias e de não ficção.

${ }^{5}$ Além de estar fora da área central de São Paulo, a periferia também alude a um espaço da "falta", sendo "associada a baixos salários e à distância em relação aos pontos onde se concentra a oferta de equipamentos culturais” (Tennina, 2017, p. 24).
} 
monólogos. Com relação às personagens femininas, Regina Dalcastagnè $(2016$, s.p.) aponta, de maneira perspicaz, que:

Embora o autor se preocupe em trazê-las para o centro de algumas histórias, elas ainda são basicamente as mães e avós, senhoras abnegadas a visitar o marido na prisão, a preparar a comida para o filho no hospício, a chorar a filha perdida. São, em suma, menos plurais e menos complexas que os homens que circulam por ali.

A observação da crítica corrobora as conclusões de Lucía Tennina (2017, p. 176), em seu estudo de largo fôlego acerca da literatura periférica paulistana, quando esta nota que "muitos romances publicados por autores da literatura marginal da periferia constroem uma representação das mulheres e do mundo feminino enraizada no esquema de gênero que instala em uma posição de poder o 'ser homem' e em uma posição de debilidade e dominação o 'ser mulher'". De fato, as personagens femininas em Reza de mãe são, em sua maioria, limitadas a papéis sociais tradicionais. Contudo, como ressalva a própria Dalcastagnè: "Isso não impede que Allan da Rosa construa uma narrativa impactante sobre a culpabilização das mulheres que abortam, em 'O jogo da velha,' por exemplo, mesmo que seja a partir da perspectiva do filho" (2016, s.p.). Expandindo essa perspectiva, argumento que, em "Pode ligar o chuveiro?" e "Reza de mãe", Rosa desconstrói a narrativa cristalizada sobre a mulher afro-brasileira e o faz a partir da elaboração de personagens femininas que estabelecem um embate de forças entre uma realidade opressora e a possibilidade de resistência.

\section{"Encantos que brotam em meio à lameira"}

Todas as histórias da coletânea gravitam em torno do duro cotidiano dos afro-brasileiros em comunidades de São Paulo, no entanto, algumas oferecem um contraponto a esse cenário desolador. No conto de abertura do volume, "Pode ligar o chuveiro?", o leitor se depara com a precária infraestrutura dos bairros periféricos, em que a energia elétrica é compartilhada por duas casas, de modo que "antes de tomar banho, tem que gritar se alguém noutra casa lá embaixo tá no chuveiro. Senão é queda. [...] Banho gelado de cano" (Rosa, 2016b, p. 7). Banho após banho, desfila diante do leitor uma galeria de personagens que se desnuda literal e figurativamente no contato com a água. Homens, mulheres, adolescentes e crianças da mesma família que, apesar das diferenças, possuem algo em comum. Todos experimentam o banho como um ritual. Para alguns, lavar o corpo equivale a uma tentativa de retirar as impurezas sujidade emocional - que acumularam ao longo de uma vida injusta. ${ }^{6}$ Para outras, e aqui me refiro especificamente a duas personagens femininas, o momento do banho corresponde a um instante de fértil potencial e de encontro consigo mesmas.

A primeira delas é Nefertiti, adolescente que explora sua sexualidade durante o banho: "Água quente invadindo o lábio, caldosa, borbulhosa. Espuma dissolve. Primeiro o rodo triscando nas bordas, depois o chuveirinho encaixado no rego. Galopa. Um pé pisa no outro, o dedão aperta o mindiiiii... aiiii aiaiaiai que saboroso" (Rosa, 2016b, p. 10). Encerrada nas quatro paredes do precário banheiro, Nefertiti é livre para expressar a atração que sente pela colega de colégio: "Na escola há de sapecar um chameguin na musa" (p. 10). Assim, a sexualidade da moça exibe outro nível de complexidade quando é revelado ao leitor seu desejo por uma amiga do mesmo sexo. É, pois, contraditoriamente num espaço de dimensões restritas que a descoberta sexual da adolescente se expande em toda sua liberdade, para além das amarras sociais de gênero. Para a adolescente, o ato corriqueiro de tomar banho revela a importância da mediação do corpo na construção da subjetividade feminina. O corpo feminino ocupa, portanto, lugar de destaque na experiência vivida e, consequentemente, no entendimento de mundo da personagem.

\footnotetext{
${ }^{6}$ Alguns dos personagens que revelam esse comportamento são Valdeci e Don Tebas de Jenê. Vendedor de uma banca de churros em porta de escola de rico, Valdeci tenta se livrar das humilhações diárias na hora do banho: "Esfrega, quase se lixa, mas dá sábado, dá domingo e esse açúcar não larga nas dobrinhas do braço. Humilhação grudada, raiva peguenta" (Rosa, 2016b, p. 8). Don Tebas de Jenê, o patriarca da família, por sua vez, tinha mania de "esfregar os dedos até sangrar" (p. 11) desde que a filha, ainda menina, havia confessado a vergonha que sentia do pai pedreiro a acariciando com mãos cheias de cimento na frente das amigas da escola.
} 
A construção da sexualidade de Nefertiti ganha dimensões ainda maiores ao se levar em consideração a representação da mulher afro-brasileira na nossa sociedade patriarcal. Ao discorrer sobre o tema, A. Gilliam e O. Gilliam (1995, p. 529) observam que essas mulheres são sexualizadas em sua juventude, têm sua mão de obra escravizada ou explorada de forma barata na vida adulta ou são, ainda, nutridoras e zeladoras quando alcançam mais idade. Nos contos de Rosa observa-se o esforço de ir além dessa representação cristalizada. É importante ressaltar, ainda, o papel da corporalidade no processo de rompimento com visões estereotipadas, pois, como argumenta Emanuelle Oliveira (2008), tanto o controle sobre seu corpo como a celebração da sua sexualidade são fundamentais para a liberação material e simbólica das mulheres afrobrasileiras. Além disso, em Reza de mãe, o narrador descreve a cena de masturbação feminina da personagem Nefertiti de maneira sutil e delicada, evidenciando o potencial libertador que tal vivência encerra tanto para a formação da sua identidade como para seu desvencilhamento de um discurso heteronormativo estigmatizante. Em outras palavras, em oposição à visão tradicional de hipersexualização do corpo da mulher negra, observa-se no conto um corpo feminino afro-brasileiro agente de sua própria sexualidade.

A segunda personagem que experimenta um encontro consigo mesma no ato de se banhar é a matriarca da família, Dona Esperança. No momento do banho, ela relembra o pai e o fato de quase ter sido registrada com o nome de Vingança:

No banho, às sextas-feiras, Dona Esperança recordava do pai. No fim da lavação, ela deixava só pingando o nome na cabeça, uma a uma cada bolinha d'água, cada gota era uma voz chamando Vingança no detalhe, na orelha, uma lembrança pingando no nariz, um cristal da voz de seu Avelino emaranhando no cabelo, outro fio d'água na nuca. Dona Vingança guardava sua caminhada e limpava o cultivo. Numa gota cabe o mar (Rosa, 2016b, p. 14).

O desencadeamento das memórias ocorre simbioticamente no contato com a água. À medida que as gotas encostam no corpo da senhora, suas memórias vêm à superfície, como que ativadas pelo toque da água. Essa sintonia entre corpo e mente faz do banho um ato transcendente que transporta a personagem para longe do pequeno banheiro no quintal em direção à sua remota origem. O poder do ato memorialístico, por sua vez, se desvela na frase "numa gota cabe o mar", no sentido de que em cada gota aflora uma memória e seu conjunto figura como símbolo para a vida em sua inteireza. Em um momento da vida no qual a mulher afro-brasileira não passa de nutridora da família, Dona Esperança se concentra em sua subjetividade ao resgatar sua vida pregressa.

Aproximando as duas personagens, observa-se que, enquanto em Nefertiti há descoberta, em Dona Esperança há redescoberta, ambos movimentos delineadores de subjetividade, esta entendida como em permanente transformação. Ao ser redimensionado como espaço simbólico, o banho, uma atividade do cotidiano de aparente desimportância, revela-se como âmbito no qual a mulher afro-brasileira, mesmo que por um instante, retira-se de um ambiente social hostil e se permite ser agente de sua trajetória. Desse modo, o banheiro improvisado no fundo do quintal, espaço precarizado imposto por uma ordem social desumanizadora, é ressignificado e as personagens utilizam o breve momento do banho para captar as possibilidades oferecidas por um instante (Certeau, 1998). Ainda de acordo com Certeau, essa hábil utilização do tempo transforma um espaço em não lugar, resistência que se aproveita das brechas do sistema para engendrar subjetividade. $\mathrm{O}$ ato de tomar banho devolve a essas personagens a individualidade que lhes é negada. É, portanto, nesse espaço, que Nefertiti descobre seu corpo e se descobre mulher, e Dona Esperança recorda as memórias que a compõem.

A rotina desumanizadora na qual vive a maior parte dos brasileiros é o mote do conto que dá título à coletânea. "Reza de mãe" narra a história de Pérola e sua filha Lavanda que, devido ao cotidiano extenuante de trabalho da mãe, mal conseguem se falar durante a semana, posto que a mãe sai para trabalhar antes de a filha despertar e quando regressa à casa, já a encontra dormindo: "Eu só vejo minha princesa dormindo quando chego destroçada de noite, que antes dela levantar pra limpar a casa e ir pra escola eu já saí" (Rosa, 2016b, p. 53). Pérola parece, de fato, encaixar-se na construção socioeconômica e racial subordinada descrita por A. Gilliam e O. Gilliam, pois, além de ser uma personagem construída como mãe, seu trabalho é descrito como "matadouro" 
(Rosa, 2016b, p. 53) e ela sofre tentativa de abuso sexual por parte do irmão Riva, episódio no qual perde um pedaço da orelha devido à audácia de não permitir a realização do ato.

Além do estado de submoradia no qual Pérola se encontra, mal podendo confiar na segurança da porta do barraco, já que ora a chave não roda na fechadura, ora a maçaneta bamba sai na mão (Rosa, 2016b, p. 54), o transporte público precário também se mostra como componente de um cotidiano opressor, no qual a lotação equivale à tortura, as pessoas se acotovelam e dormem sentadas ou em pé e as mulheres aprendem a diferenciar assédio sexual de corpos apenas em intensa proximidade (Rosa, 2016b, p. 56). Contudo, apesar de esses espaços serem propícios a um processo de dessensibilização do indivíduo, Pérola burla as estratégias institucionalizadas por um sistema opressor ao fazer amizade com um homem no transporte público, ao contar histórias para a filha dormir e ao rezar pela sua proteção ao chegar em casa. O narrador onisciente detalha que, no início, Pérola desconfiou do homem que havia puxado conversa no ônibus, mas, após conferir que ele sempre pegava a mesma condução e descia dois pontos antes, ela decidiu que poderiam ser colegas de pagar passagem quando o outro não tinha dinheiro e de descer na mesma parada só para conversar um pouco mais (Rosa, 2016b, p. 53). A relação entre os dois não evolui para um contato erotizado, tendo em vista que Pérola não passa de uma colega para o homem do ônibus. Essa amizade entre o homem e a mulher anuncia uma reconstrução da mulher afro-brasileira, na qual esta se delineia como confidente de um homem, distanciando-se dos papéis tradicionais enumerados por A. Gilliam e O. Gilliam. Além disso, a amizade que surge no espaço improvável do transporte público brasileiro se revela, tal qual o ato de tomar banho, como tática, ou "maneira de fazer", que se infiltra na ordem dominante, fortificando assim a posição do mais fraco (Certeau, 1998, p. 102).

Ao chegar em casa todos os dias, Pérola conta histórias a Lavanda, mesmo que muitas das vezes a menina já esteja dormindo: "A princesa dorme. [...] Bem miudinho, deita no mesmo travesseiro e conta. Cochicha em camisola. Pra quem?" (Rosa, 2016b, p. 54). Talvez as histórias acalentem tanto a mãe quanto a menina. ${ }^{7}$ Ao instaurar a sensação de estranhamento com a realidade, as narrações contadas por Pérola podem ser entendidas como fantásticas com seu barraco transformado em ninho de sonhar e com o homem lambuzado de bosta de galinha que ouvia todos os sons do mundo. ${ }^{8}$ A primeira delas conta a história de mulheres sonhadoras que voam nas asas de um pardal machucado que se transforma em cadela branca. A cachorra, por sua vez, ajuda homens cansados a passarem por uma espécie de ritual de limpeza para poderem entrar no barraco e reaprenderem a sonhar:

Era uma vez um barraco de sonhar. Ouvia pés tamborzando no chão, multidão de solas a caminho [...] As mulheres sonhavam, raízes, aladas, e plenas de lucidez compreenderam os temporais que derramavam nas esquinas e regras do seu sangue. Seus mormaços e suas brisas. [...] Sonharam e eram canoeiras levando a lua alumiosa em suas jangadas [...] Cada uma esperava a vez de passear montada num pardal, a ave desprezada [...] Esquecidas do medo, esse irmão gêmeo de cada uma, viam as chagas nas penas do seu transporte, o pardal avariado. Mas notavam que já galopavam numa cadela branca e soberana. [Ela] mordia com ternura as veias dos chegados para sonhar, vinham muitos homens. [...] E diante do sorriso da cachorra eles trocavam de veias para entrar [no barraco de sonhar]. Aquelas veias puídas de cada um, que surgiam na mão como o bagaço que é dado aos mendigos após a refeição dos ricos no domingo, pousavam nas palmas novas e viravam cumbucas de cheiro e borboletas azuis. [...] ali cada senhor colhia seu sonho (Rosa, 2016b, p. 54-56).

\footnotetext{
${ }^{7}$ Em leitura circular, o leitor descobre que Lavanda é filha de Bira, neto de Dona Esperança, personagens de "Pode ligar o chuveiro?". Dona Esperança reflete sobre a hombridade do neto, que é valente para as brigas na rua, mas um covarde para reconhecer a filha. A desculpa do pai é que Lavanda já tem a família materna para ajudar, Pérola e o tio Riva, e que quando ti ver condição ajudará (Rosa, 2016b, p. 16). Apesar da postura imoral do neto, Dona Esperança o trata com todas as regalias da casa de vó (faz doce de quiabo e sua casa é descrita como um útero). De maneira semelhante, a mãe de Pérola em "Reza de mãe" não repreende o filho Riva quando da tentativa de estupro da irmã. Pérola confessa que talvez tenha até passado "atestado de macheza pro fedelho" (p. 53). É importante observar que Rosa não se esquiva de abordar na sua narrativa as incoerências e preconceitos da própria comunidade afro-brasileira.

${ }^{8}$ A presente análise se restringirá à primeira história.
} 
O fantástico das histórias parece corresponder inversamente ao absurdo da rotina das duas. Enquanto a realidade do cotidiano é inverossímil no que tange a seu caráter desumanizador (Pérola pensa na invenção de uma máquina para que pudesse acompanhar a filha do seu local de trabalho), as narrativas de Pérola são inverossímeis precisamente para que ela e Lavanda possam escapar, mesmo que momentaneamente, de um cotidiano que as aliena do contato de uma com a outra. Certeau (1998) aponta que os contos populares, além de articularem uma lógica própria contrariando a cientificidade ocidental, invertem as relações de força e garantem ao oprimido a vitória num espaço maravilhoso e utópico. Sempre na base da pirâmide social, a posição da mulher afro-brasileira na história é alterada, não apenas pela possibilidade do voo, mas por ser conferida a ela a regeneração de todos os homens. Ao comentar sobre a presença do fantástico no conto "Guarde segredo", de Esmeralda Ribeiro, Emanuelle Oliveira (2008) faz duas observações que também podem iluminar a leitura da personagem Pérola: primeiro, aprisionadas pelas demandas sociais, essas mulheres se esforçam para escapar através do poder da criação artística; segundo, as histórias de Pérola oferecem a possibilidade de leitura do inconsciente feminino negro, no qual se observa o sonho de uma sociedade justa em que sonhar é permitido. Ampliando esse raciocínio, a história do barraco transformado em ninho de sonhar reveste a imaginação de carga utópica, tanto ao oferecer a transformação do espaço, com ninho remetendo a berço, aconchego e proteção, quanto ao conferir à mulher afro-brasileira o poder da cura, pois, por meio da relação harmônica entre mulher e natureza, a humanidade pode se curar e ser capaz de sonhar novamente.

Além da resistência ao cotidiano opressor por meio das histórias, Pérola também reza todas as noites para sua cabocla proteger a filha: "Minha Rainha, agradeço esse teto, a janta e a força pra trabalhar. Guarnece os lábios de minha menina. Defende o que sai, limpa o que entra. Desinfeta os parasitas, mata as bicheiras e abre fartura pra Lavanda. [...] Agradeço, Minha Rainha. Olha ela por mim quando eu me arrasto" (Rosa, 2016b, p. 57). A reza íntima e sussurada, logo antes de a mãe adormecer de exaustão, "cria um espaço diferente, que coexiste com aquele de uma experiência sem ilusões" (Certeau, 1998, p. 78). Nas orações, Pérola se refere à sua difícil existência com verbos como "se arrastar" e "se destroçar". As imagens de sofrimento também são reproduzidas aos domingos. Assim como nas orações, o seu único dia de folga a conduz a reflexões: "Nos domingos a certeza da derrota. Dia de enxergar com mais vagar a semana de frustração, a gangrena da impotência" (Rosa, 2016b, p. 59). Diante das reflexões de Pérola sobre a impotência que sente, as rezas ganham uma dimensão ainda mais significativa, uma vez que, de acordo com Certeau (1998), desfazem a fatalidade da ordem estabelecida. Em outras palavras, mesmo diante da constatação da impotência e do fracasso, Pérola resiste por meio da religião e a transforma "em um canto de resistência" (Certeau, 1998, p. 78). Desse modo, tanto através da arte de contar histórias e da religião, bem como da ressignificação de atos corriqueiros como tomar banho e utilizar o transporte público, a mulher afro-brasileira encontra maneiras de produzir espaços de resistência dentro do sistema que lhe foi imposto ou, nas palavras de Rosa (2016a, s.p.), elas geram "encantos que brotam em meio à lameira".

\section{Opressão e resistência: faces da experiência afro-brasileira}

Refletindo sobre as estratégias estéticas e temáticas em Reza de mãe a partir de uma leitura da poética gingadeira desenvolvida por Rosa em seu Pedagoginga, autonomia e mocambagem (2013), Luciana M. Mongim (2018, s.p.) observa que

o caráter gingante está presente no fazer literário do escritor não somente como estratégia estética presentes nos textos, ou seja, uma escrita literária que ginga com a língua, com os gêneros, com as formulações de personagens e narradores [...], mas também nas elaborações e negociações identitárias no traçado urbano, embasada[s] pela tradição afrodiaspórica e afro-brasileira.

Estendendo as considerações de Mongim, vale ressaltar, com relação à temática, que o quadro de referências utilizado por todas as personagens femininas analisadas tem como matriz a ancestralidade afro-brasileira, entendida aqui como princípio regulador das práticas e 
representações do afro-descendente (Oliveira, 2009, p. 3). Enquanto em Dona Esperança a ancestralidade se mostra presente pela memória do pai e da tradição culinária que ela mantém viva, em Pérola a ancestralidade é observada através das histórias e da religião. Esse rico legado é, por sua vez, transmitido às novas gerações, nas personagens da bisneta Nefertiti e da filha Lavanda, respectivamente.

Considerando essas práticas ancestrais como "signos de resistência" (Oliveira, 2009, p. 3) e adentrando o âmbito estético da obra, tanto o poema introdutório quanto o conto "O barco" permitem uma leitura dialógica com "Pode ligar o chuveiro?" e "Reza de mãe", na medida em que se acercam formando uma moldura temática, pois o poema é fundamentado na estratégia por meio da criação de um espaço de opressão socioespacial - e o conto é baseado na tática - no que ele possui de criatividade tenaz e incansável, mobilizado à espera de qualquer ocasião para resistir (Certeau, 1998, p. 102). Intitulado "Desculpa perguntar", o poema introdutório é organizado por estrofes que se iniciam com uma pergunta, por exemplo: "Já sentiu desespero, mano?". Estrofe por estrofe, o eu lírico indaga o interlocutor sobre experiências relacionadas à opressão que vão permear as páginas da coletânea, tais como desespero, humilhação, vergonha, fracasso, hipocrisia e saudade. Nesse sentido, segundo Mongim (2018, s.p.): “Em cada uma das perguntas, formuladas a partir da própria experiência do eu lírico, há aspectos do cotidiano e das vivências dos sujeitos que transitam nas periferias das cidades".

Contudo, à medida que os contos detalham as experiências antecipadas nos versos do poema, o conto "O barco" oferece um contraponto fundamentado na resistência. Trata-se de um apólogo, narrativa simbólica que personifica seres inanimados, em que um barco se encontra atracado no deserto e aguarda pacientemente pelo dia que retornará ao seu ambiente natural, a água. Durante sua longa espera, seus remos inquietos se mexem, ele proseia sozinho e tem tanto memórias felizes como doloridas do carinho da água. De tanto esperar, percebe um dia, "quase sem certeza, que perdera as características de barco: era agora casa, de pele áspera" (Rosa, 2016b, p. 46). É precisamente nesse momento que se dá uma reviravolta na curta narrativa, o barco nota que "a larga espera era também uma soltura fresca na zonzeira febril do deserto" (p. 46). Logo em seguida, aparece uma ventania e o barco, deduzindo o quanto ele tinha de água, "aceitou o convite da Ventania e inventou-se nave" (p. 46). No auge da paralisia opressora que sofre, o barco compreende que tudo contém seu oposto e entra em contato com a potência da liberdade, advinda da sua capacidade de resistir. Por meio do voo, ele, agora "pássaro, pedra, pipa" (p. 46), descobre nova beleza, as múltiplas cores da água. Os dois gêneros - poema e apólogo - fogem do gênero preponderante da coletânea, o conto, contudo a ele aludem por serem diferentes, mas faces complementares da experiência afro-brasileira: opressão e resistência.

A resistência também é urdida a partir do espaço simbólico da linguagem. ${ }^{9}$ As personagens femininas possuem nomes que redimensionam positivamente a mulher afro-brasileira: Pérola, Lavanda, Esperança/Vingança e Nefertiti. Enquanto Pérola se associa a algo de imenso valor por ser raro, Lavanda, por sua vez, é uma flor conhecida pela beleza e pelo perfume. Contrastando com o uso estereotipado que equivale mulher à delicadeza, a escolha dos nomes das personagens pode ser vista como uma intervenção estética em um cotidiano de brutalidade. Os demais nomes próprios também ilustram ajustes estéticos que fazem reverberar uma sonoridade negra e periférica (Dalcastagnè, 2016). Nomeada em homenagem à poderosa rainha do Egito no século 14 a.C., cujo nome significa "é chegada a bela", Nefertiti é criada sob uma perspectiva de enaltecimento da mulher afro-brasileira. A história da personagem coincide com a da figura histórica no que tange à vida cotidiana. Tal como a Nefertiti brasileira, a rainha egípcia é historicamente retratada em cenas cotidianas, nas quais se explicita a intimidade familiar com o marido e as filhas (Lima, 2008, s.p.). Nesse contexto, a ênfase na vida cotidiana ajuda a construir essas figuras femininas diante, respectivamente, do povo e dos leitores. No caso da rainha, as cenas íntimas, talhadas em blocos de pedra, atestam não apenas sua popularidade como seu status de deusa encarnada. Nos desenhos, seu tamanho é comparável à

\footnotetext{
${ }^{9}$ Apesar de não fazer parte da análise deste estudo, vale ressaltar que na narrativa de Rosa é forte a presença da oralidade e de um léxico afro-brasileiro. Ver Mongin (2018) e Dalscastagnè (2016).
} 
estatura do faraó, uma representação do seu poder único entre as rainhas da época. No caso da personagem, além de seu nome lhe conferir ares nobres, sua construção na intimidade do banho revela ao leitor a delicadeza da descoberta do corpo por uma jovem afro-brasileira. A sexualidade da mulher afro-brasileira, assim, é ressignificada para lhe conferir agência.

No que diz respeito à Dona Esperança, em seu nome se encontra uma importante chave interpretativa acerca do ato de resistir. Nascida num arraial distante do povoado mais próximo, a menina levou tempo para ser registrada. Quando o pai pôde finalmente ir ao cartório, seu desejo de registrar a filha com o nome de Vingança foi barrado pelo escrevente. Mesmo conhecendo a força da língua dos seus ancestrais - pois "já tinha visto um malungo derrubar uma barona em poça de sangue só com arrepio de palavra benguela, só no golpe de saliva" (Rosa, 2016b, p. 13), o pai sabia que, diante da lei, "manda quem pode, obedece quem tem juízo" (p. 13). Em casa, porém, o pai "sempre chamou a menina de Vingança, carinhoso" (p. 14). Ainda após a pressuposição de que a menina acaba sendo registrada com o nome de Esperança, porque assim é apresentada na narrativa, o leitor permanece com a indagação sobre o porquê do nome próprio Vingança. O narrador revela que o nome havia sido desejado "por todos os meses de barriga de mãe" (p. 13). Em termos etimológicos, o verbo vingar tem duas acepções bastante diferentes entre si: ao passo que significa exercer punição ou castigo sobre, também denota ter sucesso ou êxito. Nascida numa comunidade afro-brasileira no interior do país, onde a ausência do Estado é indiscutivelmente predominante, a vida de Vingança é em si um ato de resistência. De um lado, apesar de a realidade opressora indicar o contrário, a menina sobreviveu, vingou, ${ }^{10}$ de outro, o desejo de registrar a filha com um nome aparentemente tão negativo pode ser ressignificado como um ato de vingança contra o sistema que, a despeito da violência simbólica e concreta que exerce historicamente sobre a população marginalizada, não consegue controlar o âmago desses indivíduos. Dentro de casa, no âmbito íntimo do lar, o pai chamava a menina carinhosamente como havia desejado. Em última instância, prevaleceu sua palavra. O pai criou um ato de resistência ou, nos termos de Certeau, uma tática, para que seu desejo fosse respeitado.

Diante desse contexto contemporâneo de opressão e resistência, analisado pelo viés interpretativo da teoria do cotidiano de Certeau, na qual os conceitos de "estratégia" e "tática" ocupam espaço central, Rosa não só articula as variáveis de raça e gênero em seus contos, mas também desvela um substrato feminino fértil e poderoso, conferindo visibilidade à mulher afrobrasileira, no que tange ao seu protagonismo na história de resistência afro-brasileira. Alinhando-se à reflexão de Eliane Brum, os contos de Rosa aqui analisados articulam uma resistência que emerge do cotidiano. Por fim, em Reza de mãe "conseguimos ouvir algo que ficava encoberto pela voz lamuriante da classe média, ou pela potente soberba de nossas elites" (Dalcastagnè, 2016, s.p.). Afinemos, portanto, nossa capacidade auditiva e nos permitamos descobrir com as mulheres afro-brasileiras "aquilo que nos faz humanos".

\section{Referências}

ALLAN da Rosa (2018). Literafro, Belo Horizonte, 14 maio. Disponível em: http://www.letras.ufmg.br/literafro/autores/506-allan-da-rosa. Acesso em: 26 jan. 2020.

BICALHO, Gustavo (2018). Cortes abissais e costuras periféricas nos textos de Allan da Rosa. Literafro, Belo Horizonte, 7 fev. Disponível em: http:/ / bit.ly/3bilC6A. Acesso em: 18 jan. 2020.

BRUM, Eliane (2019). Doente de Brasil: como resistir ao adoecimento num país (des)controlado pelo perverso da autoverdade. El País, 2 ago. Disponível em: http://bit.ly/3c0nyjk. Acesso em: 12 out. 2019.

CERTEAU, Michel de (1998). A invenção do cotidiano. Tradução de Ephraim Ferreira Alves. Petrópolis: Vozes.

DALCASTAGNÈ, Regina (2016). Sobre a criação de narrativas necessárias. Pernambuco: Suplemento Cultural do Diário Oficial do Estado, n. 129. Disponível em: http:/ / bit.ly/3bjJg2z. Acesso em: 30 nov.. 2019.

\footnotetext{
${ }^{10}$ Em conversa pessoal com a colega Cristiane Lira, pude organizar minhas ideias com relação aos múltiplos sentidos do nome da personagem.
} 
DALCASTAGNÈ, Regina; LICARIÃO, Berttoni; NAKAGOME, Patrícia (Org.) (2018). Literatura e resistência. Porto Alegre: Zouk.

FIGUEIREDO, Fernanda Rodrigues de; RIBEIRO, Glauber Reggiani (2017). Artesanato poético: a valorização da periferia. Literafro, Belo Horizonte, 20 dez. Disponível em: https://bit.ly/30d3Lrw. Acesso em: 20 set. 2019.

GILLIAM, Angela; GILLIAM, Onik'a. (1995). Negociando a subjetividade de mulata no Brasil. Revista Estudos Feministas, Rio de Janeiro, n. 2, p. 525-543. Disponível em: https:/ / bit.ly/3kRRkuO. Acesso em: 12 out. 2019.

GUIMARÃES, Juca (2016). Escritor Allan da Rosa lança livro sobre personagens que "lutam para serem reconhecidos como gente". Geledés, 17 out. Disponível em: http:/ / bit.ly/3qfLFzL. Acesso em: 20 set. 2019.

LIMA, Cláudia Castro (2008). Nefertiti: uma deusa no comando. Aventuras na História. Disponível em: http:// bit.ly/3sKwyQq Acesso em: 24 jan. 2020.

MONGIM, Luciana Marquesini (2018). O corpo negro periférico e a poética gingadeira no livro Reza de $m \tilde{a} e$, de Allan da Rosa. In: CONGRESSO INTERNACIONAL AFRICANIDADES E BRASILIDADES, 2. SEMINÁRIO ACOLHENDO AS LÍNGUAS AFRICANAS, 7., CONGRESSO NACIONAL AFRICANIDADES E BRASILIDADES, 4., 17 a 20 set. 2018, Vitória. Anais [...] Vitória: Nafricab/UFES. Disponível em: http://periodicos.ufes.br/cnafricab/article/view/21866. Acesso em: 12 out. 2019.

OLIVEIRA, Eduardo (2009). Epistemologia da ancestralidade. Entrelugares - Revista de Sociopoética e Abordagens Afins, v. 1, p. 1-10. Disponível em: https://bit.ly/3c48ots. Acesso em: 14 nov. 2019.

OLIVEIRA, Emanuelle K. F. (2008). Writing Identity: the Politics of Contemporary Afro-Brazilian Literature. West Lafayette, Indiana: Purdue.

PATROCÍNIO, Paulo Roberto Tonani do (2011). Allan Santos da Rosa: um outro olhar sobre a periferia. Ipotesi, Juiz de Fora, v. 15, n. 2, especial, p. 57-69, jul./dez. Disponível em: https://bit.ly/38g29lf. Acesso em: 12 out. 2019.

ROSA, Allan da (2016a). Escritor Allan da Rosa lança livro sobre personagens que "lutam para serem reconhecidos como gente". [Entrevista a] Juca Guimarães. Geledés, 17 out. Disponível em: http:/ / bit.ly/2O6wQIN /. Acesso em: 22 set.. 2019.

ROSA, Allan da (2016b). Reza de mãe. São Paulo: Nós.

TENNINA, Lucía (2017). Cuidado com os poetas! Literatura e periferia na cidade de São Paulo. Porto Alegre: Zouk. (Coleção Estudos de Literaturas Contemporâneas). 